\title{
15. Különleges felhatalmazás különleges jogrend kihirdetése nélkül, avagy járványkezelés holland módra
}

\author{
MARINKÁS GYÖRGY
}

\section{A különleges jogrend alkotmányos és törvényi szintü szabályozása}

A holland jogrendszer négy különleges jogrendi helyzetet ismer, ${ }^{1}$ ebből kettő alkotmányos ${ }^{2}$ és törvényi szinten egyaránt rögzített, kettő pedig csak törvényi szinten. (A különleges jogrendi helyzeteket és a rájuk vonatkozó szabályokat a fejezet végén található táblázat foglalja össze áttekintő jelleggel.) Az alkotmány ${ }^{3}$ határozza meg az általános szükségállapot (algemene noodtoestand) és a korlátozott szükségállapot (beperkte noodtoestand) esetköreit. ${ }^{4}$ A szükségállapot két fajtájának részletszabályait - a kihirdetés és a hatalom gyakorlásának módját, valamint a korlátozható alapjogok körét - két törvény, a háborús állapotról szóló

1 Amint azt Anna Khakee - a Máltai Egyetem és a Policy Practice munkatársa - írja, az ilyen tagoltabb rendszerek előnyösebbek, mint az egy-két különleges jogrendi helyzetet szabályozó vagy a svájci mintájú biankó csekket garantáló megoldások, tekintve, hogy jobban elősegítik az előállott helyzetre adott adekvát választ, elkerülve a „kormányzati túlreagálást” (Khakee, 2009, 6. o.).

2 Ily módon a holland különleges jogrendi szabályozás nem tekinthető a Carl Schmitt-féle iskola követőjének (Kelemen, 2019, 3. o.).

3 Grondwet voor het Koninkrijk der Nederlanden (a továbbiakban: alkotmány).

4 Alkotmány 96. és 103. cikk.

Dr. Marinkás György, PhD

gyorgy.marinkas@mfi.gov.hu

kutató (Mádl Ferenc Összehasonlító Jogi Intézet)

adjunktus (Miskolci Egyetem Állam- és Jogtudományi Kar, Európai és Nemzetközi Jogi Intézet)

Marinkás, Gy. (2021) 'Különleges felhatalmazás különleges jogrend kihirdetése nélkül, avagy járványkezelés holland módra' in Nagy, Z., Horváth, A. (szerk.) A különleges jogrend és nemzeti szabályozási modelljei, 341357. o. Budapest: Mádl Ferenc Összehasonlító Jogi Intézet.

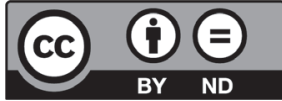


törvény ${ }^{5}$ és a különleges helyzetekről szóló törvény ${ }^{6}$ határozza meg, amelyeket 1996-ban egy átfogó reform keretében fogadtak el.

A különleges jogrend másik két esetét az alkotmány nem rögzíti, azokat - egy újabb átfogó törvényi reform eredményeként - a biztonsági körzetekről szóló törvényben ${ }^{7 o ̈ g z i ́-~}$ tették. A törvény meghatározza a katasztrófahelyzet és a krízishelyzet fogalmát, valamint az ilyen helyzetekben cselekvésre jogosultak körét és azok feladatait.

A koronavírus-járvány kezelése érdekében a négy különleges jogrendi helyzet közül egyiket sem hirdették ki. ${ }^{8}$ Jóllehet a krízishelyzet kihirdetése a külső szemlélő számára kézenfekvő döntés lett volna a kormány részéről, tekintve, hogy azt - többek között - a járványos fertőző betegségek elleni fellépésre szabták, a holland kormány más utat választott: nem hirdetett ki különleges jogrendi helyzetet, és nem kért különleges felhatalmazást. Helyette a 2008-as közegészségügyi törvény9 rendelkezéseire alapozva - az abban az egészségügyi miniszterre ruházott jogkörök révén - biztosította, hogy a járvány elleni fellépés országos szinten egységes legyen. ${ }^{10} \mathrm{~A}$ kormány a Közeü.tv. által rögzített felhatalmazással élve egyrészt az önkormányzati törvény, ${ }^{11}$ valamint a Biztonsági körzetek tv. egyes rendelkezéseit léptette életbe. (A kormány által választott megoldás elemzésére és értékelésére a 3.2. pontban kerül sor.)

A magyar Alaptörvénnyel ellentétben a Különleges helyzetek tv. nem tesz különbséget külső és belső eredetû veszély között, ${ }^{12}$ azaz a hadiállapot (staat van oorlog) is szükségállapotnak (noodtoestand) minősül, vagyis nem képez önálló kategóriát. Amint fentebb említettük, a holland szabályozás korlátozott és általános szükségállapotot ismer. A kettő közötti különbség az alapjogok korlátozhatóságának mértékében és a kormányzatra ruházott jogosultságok kiterjedtségében mutatkozik meg. Korlátozott szükségállapot esetén a jogok korlátozása azt a célt szolgálja, hogy a hadsereg minél hatékonyabban láthassa el az adott területen a katasztrófaelhárítási tevékenységet, példának okáért az evakuálást, az orvosi ellátás megszervezését, valamint a közrend és közbiztonság fenntartását. Általános szükségállapot esetén a katonaság gyakorlatilag átveszi a közigazgatási szervek összes feladatát, és a kormány irányítása - valamint bizonyos szervek felügyelete mellett - rendelkezést nyer az ország összes anyagi és humánerőforrása felett. ${ }^{13}$

Az alkotmány törvényi útra tereli a részletszabályok megállapítását azt illetően, hogy mely esetekben hirdethető ki a szükségállapot „a belső és külső biztonság fenntartásához”,

5 Oorlogswet voor Nederland (Wet van 3 april 1996) (a továbbiakban: Háborús tv.).

6 Coördinatiewet uitzonderingstoestanden (Wet van 3 april 1996) (a továbbiakban: Különleges helyzetek tv.).

7 Wet veiligheidsregio's (Wet van 11 februari 2010) (a továbbiakban: Biztonsági körzetek tv.).

8 Bentzen et al., 2020, 7-9. o.

9 Wet publieke gezondheid (Wet van 9 oktober 2008) (a továbbiakban: Közeü.tv.).

10 Cavalcanti-Terstegge, 2020, 1702. o.

11 Gemeentewet (Wet van 14 februari 1992) (a továbbiakban: Önkormányzati tv.).

12 Különleges helyzetek tv. 1. \$(1) bekezdés.

13 A két szükségállapoti helyzet egyszerre értelemszerúen nem rendelhető el (Cavalcanti-Terstegge, 2020, 1704. o.). 
és hogy a szükségállapot kihirdetését követően a jogalkalmazó milyen felhatalmazást kap, illetve mely alapjogokat korlátozhatja..$^{14}$

Az általános és korlátozott szükségállapot kihirdetésére okot adó körülményeket a Különleges helyzetek tv. rögzíti: amennyiben a különleges körülmények azt szükségessé teszik, a miniszterelnök javaslatára az uralkodó királyi rendeletben hirdeti ki a korlátozott vagy az általános szükségállapotot. ${ }^{15} \mathrm{~A}$ rendeletet a hivatalos lapban kell közzétenni. ${ }^{16}$

Az alkotmány értelmében hadiállapotot csak a parlament előzetes hozzájárulásával lehet kihirdetni, ${ }^{17}$ erről a két kamara együttes ülésen dönt. ${ }^{18}$ Ezalól kivételt képez az a helyzet, amikor a ténylegesen fennálló hadiállapot miatt a törvényhozással való konzultáció kivitelezhetetlen. ${ }^{19}$ (A háború befejeztének kihirdetésére az előbbi rendelkezéseket kell alkalmazni.) ${ }^{20}$ Említést érdemel továbbá, hogy önmagában a háborús állapot deklarálása, amennyiben arra a szövetségi kötelezettségek ${ }^{21}$ teljesítése végett kerül sor, az Alaptörvény kilencedik módosítása révén 2023-tól hatályba lépő magyar szabályozási megoldással ellentétben nem jár különleges jogrendi állapot kihirdetésével. (Az ezzel kapcsolatos holland közjogi vitákat lásd a 4. pontban.)

A katasztrófahelyzet és a krízishelyzet fogalmát a Biztonsági körzetek tv. rögzíti. ${ }^{22} \mathrm{~A}$ katasztrófahelyzet olyan helyzetet jelöl, amely komolyan fenyegeti vagy veszélyezteti az állampolgárok életét és jólétét, illetve a természeti és épített környezetet, és amelynek elhárítása, illetve a károk csökkentése érdekében a hatóságok és egyéb szervezetek összehangolt munkája szükséges. Ez utóbbi megfeleltethető a magyar Alaptörvény 53. cikkének. ${ }^{23} \mathrm{~A}$ krízishelyzet a társadalom alapvető érdekeit veszélyeztető eseményt - példának okáért nukleáris balesetet vagy fertőző betegség okozta járványt - vagy az ilyen esemény bekövetkeztével fenyegető helyzetet jelent. ${ }^{24}$

A katasztrófa- és a krízishelyzet közötti elhatárolás alapja alapvetően az irányítás centralizált vagy decentralizált voltában nyilvánul meg: a katasztrófahelyzetek (például kisebb ipari balesetek, árvizek) elhárítása a Biztonsági körzetek tv. értelmében alapvetően a helyi önkormányzatok feladata, ${ }^{25}$ amelyek csak akkor kérnek tartományi vagy kormányzati szintû beavatkozást, amennyiben a feladat helyi szinten kezelhetetlennek bizonyul. ${ }^{26} \mathrm{~A}$ krízis-

14 Alkotmány 103. cikk (1) bekezdés.

15 Különleges helyzetek tv. 1. cikk (1) bekezdés.

16 Különleges helyzetek tv. 1. cikk (3) bekezdés.

17 Alkotmány 96. cikk (1) bekezdés.

18 Alkotmány 96. cikk (3) bekezdés.

19 Alkotmány 96. cikk (2) bekezdés.

20 Alkotmány 96. cikk (4) bekezdés.

21 Például a NATO-szerződés 5. cikke alapján.

22 Biztonsági körzetek tv. 1. \$ (1) bekezdés.

23 Az Alaptörvény 53. cikkét illetően lásd: Horváth, 2020.

24 Kuipers-Boin, 2014, 8-9. o.

25 Biztonsági körzetek tv. 2. cikk.

26 A katasztrófahelyzetek idején alkalmazott holland gyakorlat azt mutatja, hogy a hadsereg bevonását - amennyire lehetséges - igyekeznek kerülni; jóllehet volt arra példa, hogy igénybe vették, elsősorban a lakosság evakuálásának hatékony lebonyolítása érdekében. Lásd: Kuipers-Boin, 2014, 8-9. o. 
helyzet elhárítása ezzel szemben vagy a biztonsági körzetek szintjén - a kormány esetleges iránymutatásával -, vagy centralizáltan, közvetlenül a kormány irányítása alatt történik.

A Biztonsági körzetek tv. a katasztrófahelyzet elhárítását elsődlegesen az önkormányzatok feladatává teszi, a polgármestert jelöli meg mint a katasztrófaelhárítás koordinálásáért felelős személyt. ${ }^{27} \mathrm{Az}$ Önkormányzati tv. rögzíti a polgármesterek ehhez kapcsolódó, a közrend és közbiztonság fenntartására irányuló hatásköreit. ${ }^{28}$ Kiemelendő, hogy a polgármesterek szükséghelyzeti határozatot (noodbevelen) vagy szükséghelyzeti rendeletet (noodverordeningen) bocsáthatnak ki. ${ }^{29} \mathrm{~A}$ kettő közötti különbség, amint azt az Államtanács ${ }^{30}$ Közigazgatási Kollégiuma $^{31}$ egy 2019-es ügyben ${ }^{32}$ kifejtette, hogy míg az előbbi közigazgatási jellegú aktus, amely meghatározott személyt vagy személyek egy csoportját kötelezi egy meghatározott feladat kapcsán, utóbbi általános hatályú, „kvázi törvényhozási” aktus, amely mindenkire vonatkozik az önkormányzat illetékességi területén, és jellemzően huzamosabb ideig marad érvényben. Ennek megfelelően utóbbi elfogadása esetében több eljárási garancia érvényesülését is megkívánja a törvény: egyrészről az intézkedéseknek meg kell felelniük az alkotmány rendelkezéseinek, másrészről a rendelkezéseket jóvá kell hagynia az önkormányzat tanácsának, ${ }^{33}$ majd pedig továbbítani kell azt a tartomány vezetőjének,,34 illetve a körzeti ügyészség vezetőjének. Az önkormányzat tanácsának jóváhagyása a demokratikus kontroll miatt bír kiemelkedő fontossággal: a polgármesterek Hollandiában nem választott tisztségviselők - a bel- és igazságügyi miniszter nevezi ki őket az önkormányzat tanácsa és a tartomány vezetőjének javaslatára ${ }^{35}$-, így a demokratikus kontrollt a közvetlenül választott önkormányzati tanács gyakorolja a tevékenységük felett. ${ }^{36} \mathrm{E}$ kontroll magában foglalja a fent említett jóváhagyást. Amennyiben a tanács nem hagyja jóvá a szükséghelyzeti rendeletet az elfogadását követô első ülésén, úgy annak hatálya megszû́nik. ${ }^{37} \mathrm{~A}$ két instrumentum közötti különbség az ellenük benyújtható jogorvoslatok terén is megmutatkozik: míg előbbi ellen a közigazgatási bíróságok előtt indítható eljárás, utóbbi a rendes polgári bíróság elôtt támadható meg, és a hatályon kívül helyezésére

27 Biztonsági körzetek tv. 5. cikk.

28 Önkormányzati tv. 172-177. cikk.

29 Önkormányzati tv. 175. cikk.

30 Hollandiában az Államtanács (Raad van State) kettős funkcióval bír: egyrészrôl független tanácsadó szervként segíti a kormány és a parlament munkáját törvényhozási és közigazgatási ügyekben. Másrészről az állam legfelsőbb közigazgatási bírói fórumaként jár el. Ez utóbbi funkciót egy 1963-as törvényhozási reform ruházta az Államtanácsra. Az említett reform arról is rendelkezett, hogy az Államtanács tanácsadói és a bírói funkciót ellátó két ága személyileg és szervezetileg is elkülönül egymástól. Előbbi tíz főbool áll, elnöke a mindenkori uralkodó. Utóbbi ágában pedig hivatásos bírák látják el a szolgálatot. Lásd az Államtanács honlapját: www. raadvanstate.nl/overrvs/raad-state-kort/ (Letöltve: 2020. december 15.).

31 De Afdeling Bestuursrechtspraak van de Raad van State (ABRvS).

32 ABRvS, 201900824/1/A3 (18.12.2019).

33 Gemeenteraad.

34 Commissaris van de Koning (CvdK).

35 Önkormányzati tv. 61. cikk.

36 Önkormányzati tv. 10. cikk.

37 Önkormányzati tv. 176. cikk (3) bekezdés. 
csak abban az esetben van lehetőség, amennyiben ellentétes a jogszabályi hierarchiában felette álló normákkal és a jogrendszer alapvető elveivel.

Az önkormányzatok kompetenciáját meghaladó rendkívüli események kezelése a biztonsági körzet vezetőjéboól ${ }^{38}$ és a körzetébe ${ }^{39}$ tartozó polgármesterekből álló testület (bestuur van de veiligheidsregio) feladata. ${ }^{40} \mathrm{~A}$ testület többségi szavazással dönt; ${ }^{41}$ szavazategyenlőség esetén a biztonsági körzet vezetôjének szavazata dönt. A testület üléseire ${ }^{42}$ tanácskozási joggal meghívják a legfőbb körzeti ügyészt, a területileg illetékes vízügyi főhatóság vezetőjét, valamint a tartomány vezetőjét. Utóbbi akkor jut szerephez mint „döntőbíró”, ha valamilyen hatásköri összeütközés áll fenn. ${ }^{43} \mathrm{~A}$ biztonsági körzetek említett testülete felelős a szükséghelyzeti cselekvési terv ${ }^{44}$ kidolgozásáért és annak legalább négyévente történő felülvizsgálatáért.

A Biztonsági körzetek tv. rögzíti a több biztonsági körzetet érintő krízishelyzetek esetén alkalmazandó szabályokat. ${ }^{45}$ Jóllehet a polgármesterek ez esetben is véleményt nyilváníthatnak előzetesen - illetve utólag tiltakozást nyújthatnak be -, a törvény 39-43. cikkének értelmezéséből az következik, hogy ez esetben a helyi önkormányzatok csak végrehajtói a biztonsági körzetek vezetőin keresztül érvényesülő, a kormánytól és a tartományok vezetőitől érkező utasításoknak. A krízishelyzet esetén követendő protokollt országos szinten a 2016. szeptember 6-i miniszterelnöki rendelet, ${ }^{46}$ valamint a Krízishelyzetekben történő döntéshozatalról szóló nemzeti útmutató címú dokumentum ${ }^{47}$ szabályozza, amelyek meghatározzák a Miniszteri Szintû Válságkezelő Bizottság, valamint a többi, a válságkezelésben részt vevő szerv és intézmény ${ }^{48}$ összetételét és feladatait.

38 A biztonsági körzetek vezetőit a Biztonsági körzetek tv. 11. cikke értelmében királyi rendelet útján nevezik ki és királyi rendelet útján menesztik, amennyiben az szükséges. A kinevezést megelőzően a biztonsági körzetbe tartozó polgármesterek és az adott tartomány vezetôje véleményt nyilváníthatnak a jelöltet illetően.

39 A Biztonsági körzetek tv. 8. cikkének melléklete tartalmazza az önkormányzatok biztonsági körzetek szerinti beosztását.

40 Biztonsági körzetek tv. 8. cikk.

41 Biztonsági körzetek tv. 11. cikk.

42 Biztonsági körzetek tv. 12-13. cikk.

43 Biztonsági körzetek tv. 42., 53., 59. cikkek.

44 Biztonsági körzetek tv. 14-16. cikk.

45 Biztonsági körzetek tv. 39. cikk.

46 Order of the Prime Minister (Minister of General Affairs) of 6 September 2016, no. 3889766, establishing the Ministerial Crisis Management Committee (Government Gazette, 12 September 2016, no. 48258) (a rendelet a Biztonsági körzetek tv. 37. cikkében található felhatalmazáson alapul).

47 Nationaal Handboek Crisisbesluitvorming. Közzétéve: Kormányzati Közlöny, 2013. április 24. (11207. szám). A Nemzeti Biztonsági és Terrorelhárító Központ (Nationaal Coördinator Terrorismebestrijding en Veiligheid) kiadványa: www.preventionweb.net/files/submissions/61145_nlnationalhandbookondecisionmakingincrisissi tuationsnetherlands.pdf (Letöltve: 2020. december 15.).

48 További szervek a teljesség igénye nélkül: Tanácsadó Csoport (Adviesteam), Tárcaközi Válságkezelő Bizottság (Interdepartementale Commissie Crisisbeheersing); Nemzeti Krízisközpont (Nationaal Crisiscentrum); Nemzeti Mủveleti Koordinációs Központ (Landelijk Operationeel Coördinatiecentrum); Nemzeti Biztonsági és Terrorelhárító Központ (Nationaal Coördinator Terrorismebestrijding en Veiligheid), Nemzeti Válságkommunikációs Stáb (Nationaal Kernteam Crisiscommunicatie). 


\section{Az alapjogok korlátozására vonatkozó szabályok különleges jogrend idején}

Az alkotmány felsorolja azokat az alkotmányos rendelkezéseket, illetve alapjogokat, amelyek korlátozhatók szükségállapot idején. ${ }^{49}$ Ennek megfelelően alkotmányos szinten szabályozott a következő alapjogok korlátozása: ${ }^{50}$ a vallási és a lelkiismereti szabadság körébe eső tevékenységek (6. cikk), amennyiben azok nem beltérben vagy más zárt helyen történnek; a véleménynyilvánítás és a sajtó szabadsága (7. cikk). Továbbá az egyesülési szabadság (8. cikk); a gyülekezési jog (9. cikk); a magánlakás sérthetetlenségéhez való jog (12. cikk); a levéltitokhoz való jog (13. cikk). Az alkotmány a részletszabályok megállapítását törvényi szintre utalja, ahogyan a további korlátozható jogok körét, a korlátozás részletes szabályait, valamint az általános szükséghelyzet esetén az országot irányító katonai kormányzat jogköreinek meghatározását is. Mindezeket a Különleges helyzetek tv. rögzíti a Háborús tv. paragrafusainak megjelölése révén.

Korlátozott szükséghelyzet esetén az úgynevezett "A” listás ${ }^{51}$ jogok esnek korlátozás alá. Amint fentebb utaltunk rá, az alapjogok csak az alkotmányban meghatározott mértékben korlátozhatók. A korlátozott szükségállapot elrendelése esetén a kormány - azon belül különösen a védelmi miniszter - és a hadsereg olyan jogosítványokat kap, amelyek a korlátozott szükségállapot elrendelésére okot adó körülmény elhárításához szükségesek. (Ilyen például a lakosság teljes vagy részleges kitelepítése, ezzel együtt egyes körzetek teljes lezárása, ingó és ingatlan dolgok kisajátítása, a telekommunikációs eszközök és a közúti közlekedés feletti teljes rendelkezés átvétele.)

Általános szükséghelyzet esetén az úgynevezett „B” listás jogok ${ }^{52}$ korlátozhatók. A katonai kormányzat általános sorkötelezettséget rendelhet el minden 18. életévét betöltött személy számára. Ezzel egyidejûleg az alapjogok komoly korlátozás alá esnek. Így például az alkotmányban szabályozott büntetôjogi alapelvek ${ }^{53}$ - úgymint a törvényes bíróhoz való jog a büntetőügyek elbírálása és a szabadságvesztés-büntetés kiszabása során - is csak korlátozottan, „a körülmények által lehetôvé tett mértékben” érvényesülnek. ${ }^{54}$

Katasztrófa- és krízishelyzet esetén olyan alapjogok korlátozhatók, mint a gyülekezés és az egyesülés szabadsága, a vallásszabadság, illetve az oktatáshoz és az igazságszolgálta-

49 Alkotmány 103. cikk (2) bekezdés.

50 E helyütt érdemes felhívni rá a figyelmet, hogy a holland alkotmány és a magyar Alaptörvény eltérően közelíti meg a kérdést: míg előbbi a korlátozható jogok körét sorolja fel, utóbbi azokat, amelyeket még különleges jogrend esetén sem lehet korlátozni (Khakee, 2016, 16. o.).

51 Háborús tv. 9-23. cikk.

52 Háborús tv. 9-53. cikk.

53 Alkotmány 113. cikk (1)-(3) bekezdés.

54 Háborús tv. 42. cikk. Érdemes megjegyezni, hogy a magyar Alaptörvény a holland alkotmánnyal ellentétben még különleges jogrend esetén sem töri át ezt a fontos alapjogi garanciát. Az Alaptörvény 54. cikke értelmében - többek között - a XXVIII. cikk (2)-(6) bekezdésében megállapított alapvető jogok még különleges jogrend idején sem függeszthetők fel. 
táshoz való hozzáférés. E jogok korlátozásának szabályait az alkotmány, az Önkormányzati tv. és a Biztonsági körzetek tv. rögzítik. ${ }^{55} \mathrm{~A}$ vallás- és a lelkiismereti szabadság körébe eső tevékenységek - feltéve, hogy azok nem beltérben vagy más zárt helyen kerülnek megtartásra az alkotmány alapján, ${ }^{56}$ a törvényben meghatározottak szerint korlátozhatók a közegészség védelme, a közlekedés zavartalanságának biztosítása, illetve katasztrófa megelőzése vagy elhárítása érdekében. Hasonlóképpen, a gyülekezési jog a törvényben meghatározott esetekben korlátozható a közegészség védelme, a közlekedés zavartalanságának biztosítása, illetve a katasztrófa megelőzése vagy elhárítása érdekében. ${ }^{57}$

\section{A koronavírus-járvány miatt bevezetett különleges intézkedések és az alapjogok korlátozásának alkotmányossága}

\subsection{A 2020 tavaszán bevezetett intézkedések}

A holland kormány arra az álláspontra helyezkedett, hogy a koronavírus-járvány elleni hatékony fellépés - és a lakosság egészségének megőrzése mint alkotmányos kötelezettség ${ }^{58}$ teljesítése - érdekében nem szükséges különleges jogrendi állapot kihirdetése ${ }^{59} \mathrm{~A}$ kormány által meghozott intézkedések a Közeü.tv. rendelkezésein alapultak. A törvény értelmében a fertőző betegségek a súlyosságuk szerint A, B1, B2 és C kategóriába eshetnek egy olyan skálán, amelyen az A kategória a legsúlyosabb. ${ }^{60} \mathrm{~A}$ betegség súlyosság szerinti osztályozása egyben meghatározza a kormány és a decentralizált szervek közötti feladatmegosztást, illetve a korlátozható alapjogok körét. ${ }^{61}$

Az egészségügyi miniszter a koronavírust 2020. január 28-án nyilvánította $\mathrm{A}$ kategóriás fertőző betegséggé, amelynek következtében a Közeü.tv.-ben biztosított felhatalmazással ${ }^{62}$ élve átvette a vírus elleni védekezés irányítását anélkül, hogy krízishelyzetet hirdettek volna ki. A biztonsági körzetek vezetői felhatalmazást kaptak, hogy átvegyék a védekezés megszervezésével kapcsolatos - az Önkormányzati tv.-ben rögzített ${ }^{63}$ - hatáskörök gyakorlását

55 Ezek részletesen a jelen fejezet 3. pontjában kerülnek ismertetésre.

56 Alkotmány 6. cikk (2) bekezdés.

57 Alkotmány 9. cikk (2) bekezdés.

58 Alkotmány 22. cikk (1) bekezdés.

59 Hendriks, 2020, 950. 0.

60 Közeü.tv. 1. cikk.

61 Egy A kategóriás fertőző betegség esetén például a Közeü.tv. 38. cikk (1) bekezdése értelmében az érintett az akarata ellenére és a beleegyezése nélkül is karanténba helyezhető, amennyiben azt a biztonsági körzet vezetője elrendeli. Az ilyen betegség diagnosztizálása vagy a betegség gyanúja esetén a 22. cikk (1) bekezdése értelmében az orvos jelenteni köteles a közhatalmi szervek irányába.

62 Közeü.tv. 6. cikk (4) bekezdés, 7. cikk (1) bekezdés.

63 Önkormányzati tv. 172-177. cikk. 
a polgármesterektől; továbbá az egészségügyi miniszter felhatalmazást kapott a biztonsági körzetek vezetőinek utasítására. ${ }^{64}$

Az első kormányzati szintû́ intézkedéscsomagot 2020. március 12-én jelentette be Mark Rutte miniszterelnök, az egészségügyi miniszter ugyanazon a napon kelt javaslatával ${ }^{65}$ egyező tartalommal. A kormány megtiltotta minden, száz főnél nagyobb rendezvény tartását, valamint felkérte az állampolgárokat, hogy amennyiben a koronavírus tüneteit fedezik fel magukon, úgy maradjanak otthon. Az időseket és a más okból gyenge immunrendszerrel rendelkezőket arra kérte, hogy tartózkodjanak a nagyobb létszámú csoportosulással járó események látogatásától, illetve felhívta az egészségügyben dolgozókat, hogy ne utazzanak külföldre.

A kormányzati intézkedések bejelentését követően a biztonsági körzetek vezetői kibocsátották a saját biztonsági körzetükre vonatkozó szükséghelyzeti rendeleteket. Míg e rendeletek egy része szóról szóra ismételte az egészségügyi miniszter levelében foglaltakat, más körzeti vezetők eltérő tartalommal töltötték azt meg, élve az Önkormányzati tv.-ben rögzített felhatalmazással. ${ }^{66}$ Annak érdekében, hogy a szükséghelyzeti rendeletek alkalmazása egységes módon történjen, a biztonsági körzetek vezetőinek tanácsa (veiligheidsberaad) kidolgozott egy modell szükséghelyzeti rendeletet, amelyből kiindulva minden egyes biztonsági körzet vezetője - az egészségügyért felelős miniszter felügyeleti jogának fenntartása mellett - kidolgozhatta a saját körzete igényeinek megfelelő szükséghelyzeti rendeletet.

$\mathrm{Az}$ egészségügyi miniszter 2020. március 17 -én rendelte $\mathrm{el}^{67}$ az óvodák és az oktatási intézmények, az éttermek és egyéb vendéglátóhelyek, valamint a sportlétesítmények bezárását. E rendelkezések a biztonsági körzetek vezetôi által a következő napokban elfogadott vészhelyzeti rendelkezések révén váltak kötelezővé. A miniszter 2020. március 25 -én gyakorlatilag a résztvevők számától függetlenül minden csoportosulással járó tevékenységet megtiltott, amely alól csak a városi tanácsok, a parlament és az állam múködéséhez szükséges közigazgatási szervek tevékenysége, továbbá a harminc fônél kevesebb személy részvételével tartott esküvők és temetések, valamint vallási összejövetelek képeztek kivételt - feltéve, hogy az alkalmazottak, illetve utóbbi három esetében a résztvevők maszkot viselnek.

A biztonsági körzetek vezetói - élve a törvényes felhatalmazásukkal - további rendelkezéseket hoztak: Zeeland tartományban például a biztonsági körzet vezetője betiltotta a fizetett szálláshelyek múködését. ${ }^{68}$

A fenti rendelkezések megszegésének esetére az egészségügyi miniszter pénzügyi szankciók kiszabását javasolta. A biztonsági körzetek vezetői által kibocsátott szükséghelyzeti rendeletek is jellemzően pénzügyi szankciót rendeltek alkalmazni az elő́rásokat megszegókkel szemben. Jogértelmezési kérdést vetett fel ugyanakkor, hogy a biztonsági körzet ve-

64 Biztonsági körzetek tv. 39. cikk.

65 Kamerstukken, 2019/2020, 25295, n.124.

66 Önkormányzati tv. 174. cikk.

67 Kammerstukken II, 2019/2020, 25295, n.175; Kamerstukken II, 2019/2020, 31289, n.416.

68 Noodverordening COVID-19, Veiligheidsregio Zeeland, 27 March 2020. 
zetőjének jogában áll-e közigazgatási bírság kiszabását elöírni a szükséghelyzeti rendeletben. Az Önkormányzati tv. ugyanis feljogosítja erre a polgármestert. ${ }^{69} \mathrm{~A}$ Biztonsági körzetek tv. 39. cikke ugyanakkor az Önkormányzati tv. 125. cikkében rögzített hatáskörök átszállásáról nem rendelkezik. Az igazságügyi miniszter a hozzá intézett kérdésre válaszul70 arra az álláspontra helyezkedett, hogy bár a Biztonsági körzetek tv. 39. cikke nem említi expressis verbis az Önkormányzati tv. 125. cikkét, a törvényt úgy kell értelmezni, hogy a hatáskörök átruházása magában foglalja a szankciós jogkörök átszállását is. A kérdést tisztázandó, a Közeü.tv. módosítását célzó 2020. júliusi törvényjavaslat - amelyről a 3.3. pontban esik szó részletesen expressis verbis rendelkezik a biztonsági körzetek vezetőinek szankcionálási jogáról.

A kormány a fent említett intézkedéseket 2020. május 11-én kezdte el fokozatosan feloldani, amikor az intenzív osztályon ápolt páciensek létszáma egy meghatározott szint alá csökkent. ${ }^{71}$

\subsection{A bevezetett intézkedések értékelése a jogállamiság és a demokratikus elszámoltathatóság szempontjából}

A koronavírus-járvány kapcsán hozott korlátozások értékelése során a mérlegelendő szempont, hogy az alapjogok korlátozása arányos volt-e az alkotmány 22. cikk (1) bekezdésében rögzített céllal. E mérlegelés elvégzése Hollandiában a rendes bíróságok, valamint a legfelsőbb bíróság és az Államtanács Közigazgatási Kollégiuma, illetve egyéb különleges hatáskörü bíróságok feladata. E helyütt érdemes utalni a hollandok „különutasságára”"72 e téren: Hollandiának - ellentétben a kelseni tanokkal és a többségükben e tanokat követő európai országokkal - nincs sem alkotmánybírósága, sem olyan legfelsőbb bírósága, amely a joggyakorlata fejlesztése során magának vindikálta volna a törvények alkotmányossági felülvizsgálatának jogát, ahogyan azt az Egyesült Államok legfelsőbb bírósága tette. A holland alkotmány expressis verbis tiltja a bíróságok számára, hogy alkotmányossági szempontú felülvizsgálatot végezzenek a parlament által meghozott törvények és az ország által kötött nemzetközi szerződések felett. ${ }^{73} \mathrm{E}$ hiányosságot ugyanakkor valamelyest ellensúlyozza az ország nemzetközi jog elsőbbsége iránti elkötelezettsége ${ }^{74}$ amelynek értelmében a bíróságok kötelesek „félretenni” a nemzeti jogot, amennyiben az ellentétes valamely, a személyekre közvetlenül jogot ruházó nemzetközi szerződéssel vagy valamely nemzetközi szervezet által kibocsátott határozattal, amennyiben az a személyekre közvetlenül jogot alapít.

A szakirodalom vegyes a kormány azon döntésének megítélésében, hogy nem vezetett be különleges jogrendi állapotot, valamint az általa rendes jogrend alapján hozott intéz-

69 Önkormányzati tv. 125. cikk.

70 Handelingen 2019/20, No. 2307, 01.04.2020.

71 Antonides-van Leeuwen, 2020, 4. o.

72 E különutasság kapcsán részletesen lásd: Uzman et al., 2010.

73 Alkotmány 120. cikk.

74 Alkotmány 94. cikk. 
kedések jogi szempontú megítélését illetően. Cavalanti és Terstegge szerint a Közeü.tv. és a Biztonsági körzetek tv. rendelkezései kellő jogalapot szolgáltattak a meghozott intézkedésekhez, amelyek az arányosság próbáját is kiállták. Mi több, álláspontjuk szerint a holland kormány által hozott kezdeti - az állampolgárok meggyőzésére alapuló - intézkedések túlzottan enyhék voltak a szükségeshez képest. ${ }^{75}$

A kormány a kezdeti enyhe intézkedéseket, illetve később a különleges jogrendi helyzet mellőzését azzal indokolta, hogy bízik az állampolgárok felelősségteljes magatartásában. ${ }^{76}$ Broeksteeg, ${ }^{77}$ valamint Buyse és de Lange ${ }^{78}$ ezzel szemben arra hívják fel a figyelmet, hogy a kormány tulajdonképpen azért nem hirdetett ki krízishelyzetet - vagy más különleges jogrendi helyzetet -, mert ily módon a Közeü.tv. rendelkezéseiben található „kiskaput” felhasználva úgy biztosíthatta az általa hozott intézkedések egész országban történő érvényesülését, hogy közben megkerülte a demokratikus kontrollt és az alapjogok korlátozásának alkotmányos garanciáit. A kormány a demokratikus kontroll megkerülését oly módon érte el, hogy a Közeü.tv. fent említett rendelkezéseire alapozva elvonta a polgármesterek döntési jogkörét, és a biztonsági körzetek vezetőinek kezébe helyezte azt, akik a kibocsátott szükséghelyzeti rendeleteiket nem kötelesek jóváhagyatni az önkormányzat tanácsával. Az ő esetükben, amennyiben sor kerül krízishelyzet kihirdetésére, az ellenőrzést - ám nem a demokratikus kontrollt ${ }^{79}$ - a Biztonsági körzetek tv. alapján a körzetükbe tartozó polgármesterekkel, valamint a kerületi legfőbb ügyésszel való kötelező előzetes egyeztetés, illetve a körzetbe tartozó önkormányzati tanácsok kérdezési joga garantálja ${ }^{80}$ Tekintve azonban, hogy a kormány nem hirdetett ki krízishelyzetet, a Közeü.tv. pedig nem ír elő semmilyen hasonló egyeztetési kötelezettséget, a biztonsági körzetek vezetőinek kezét még ez az előírás sem kötötte - ehelyett azok végig az egészségügyi miniszter kottájából játszottak.

A jogalkalmazás terén további problémaként jelentkezett, hogy a jogalkalmazók a koronavírus-járvány elleni védekezés során több esetben a kevesebb garanciális szabály mellett kibocsátható szükséghelyzeti határozatokat alkalmazták „kvázi szükséghelyzeti rendeletként" olyan esetekben is, amikor a törvény értelmében egyébként szükséghelyzeti rendeleteket kellett volna kibocsátaniuk. ${ }^{81}$

Az alapjogok korlátozása kapcsán Wierenga és szerzőtársai ${ }^{82}$ - valamint a fentebb említett Buyse és de Lange - az alkotmány 103. cikkének (2) bekezdésében rögzített, a vallásszabad-

75 Cavalanti-Terstegge, 2020, 1708-1709. o.

76 Továbbá, ahogyan a miniszterelnök fogalmazott: nem akar „főnököt” játszani, aki megmondja másoknak, hogy mit csináljanak (Antonides-van Leeuwen, 2020, 1. o.).

77 Broeksteeg, 2020.

78 Buyse-de Lange, 2020.

79 Emlékeztetni kell, hogy a krízishelyzet esetében helyi szinten demokratikus elszámoltathatóságról eleve nem lehet beszélni, mivel ez esetben az önkormányzatok feladata a kormány döntéseinek végrehajtása. Az intézkedésekért tehát ez esetben a kormány felel a választók előtt.

80 Biztonsági körzetek tv. 40. cikk.

81 van der Kolk, 2020 .

82 Wierenga et al., 2020. 
ságra és a gyülekezési jogra vonatkozó rendelkezéseket illetik jogállamisági optikájú kritikával. Amint írják, amennyiben a kormány szükséghelyzetet hirdetett volna, úgy kizárólag az említett alapjogok nyilvánosan történő gyakorlását korlátozhatta volna, azt is csak a törvényhozás ellenőrzése alatt, nem pedig a biztonsági körzetek vezetôi által - az egészségügyi miniszter kézi vezérlése alatt - kiadott szükséghelyzeti rendeletek útján. Amint fentebb bemutattuk, a kibocsátott szükséghelyzeti rendeletek elő́rásokat - maximális létszám, kötelező maszkviselés - tartalmaztak a zárt térben történő vallásgyakorlásra vonatkozóan, illetve minden gyülekezést betiltottak létszámtól függetlenül. További példaként említik az egészségügyi és szociális ellátóintézményekben bevezetett látogatási tilalmat, amely ellen az alkotmány, illetve a vonatkozó törvények - a kormány által választott megoldásból kifolyólag - nem garantálnak érdemi, az ellentétes jogokat és érdekeket mérlegelő felülvizsgálati fórumot az érintettek számára. E helyütt szükséges emlékeztetni a fentebb írottakra, miszerint a szükséghelyzeti rendeletek csak abban az esetben helyezhetők hatályon kívül, amennyiben ellentétesek a hierarchiában felettük álló jogszabályokkal vagy a jogrendszer alapvető elveivel.

További kritikaként említhető, hogy bár a holland parlament múködött a járványügyi megszorítások idején is, az általa érvényesített kontroll meglehetősen felületes volt. Mindez következett abból is, hogy az alsóház, ${ }^{83}$ amely rendszerint heti háromszor ülésezik, lecsökkentette az ülések számát heti egyre, a felsőhá $z^{84}$ pedig teljesen átállt az online ülésezésre. A felsőház a döntés meghozatala előtt jogértelmezést kért és kapott az Államtanácstól, amelynek álláspontja ${ }^{85}$ a következők szerint foglalható össze: a holland alkotmány nem zárja ki az online ülésezést, feltéve, hogy a nyilvánosság és a sajtó számára biztosítják, hogy az ülést videoközvetítés útján nyomon követhessék, és azt, hogy a közvetítés során a felszólaló képviselők egyértelmúen beazonosíthatók legyenek. Az Államtanács véleménye alapján azonban online szavazást nem lehet tartani, mivel a véleménykibocsátásnak az időpontjában még nem állt rendelkezésre olyan technológia, amely garantálta volna a szavazás titkosságát.

\subsection{A törvényi reform}

Az előző alpontban ismertetett kritikákra tekintettel a holland kormány 2020 júliusában benyújtott egy törvénymódosítási javaslatot, amelynek célja az volt, hogy - a fentebb ismertetett kritikákat figyelembe véve - a jogállamiság követelményének megfelelő jogalapot szolgáltasson a járvány második hulláma elleni védekezés során meghozott intézkedésekhez ${ }^{86} \mathrm{~A}$ Covid-19járvány kezeléséhez szükséges átmeneti intézkedésekról szóló törvényjavaslatot 2020. október

83 Tweede Kamer der Staten-Generaal.

84 Eerste Kamer der Staten-Generaal.

85 Raad van State (17 April 2020) Summary of Information about the Functioning of the Senate during the Corona Crisis. Elérhető: www.raadvanstate.nl/actueel/nieuws/@120871/voorlichting-eerste-kamer-coronacrisis/ (Letöltve: 2020. december 15.).

86 van den Hoven-van Genderen, 2020. 
27-én fogadták el. ${ }^{87} \mathrm{~A}$ törvény $\mathrm{X}$. fejezete értelmében a hatálybalépés dátumát királyi rendelet határozza meg. A törvény 2020. december 1-jén lépett hatályba, és iktatta be a Közeü.tv.-be az V/a. fejezetet és a fejezetet alkotó 58a-68u. cikkeket. A törvénymódosítás a VIII. cikkében a hatályon kívül helyezés dátumát is meghatározza, amelyet 2021. március 1-jében jelöltek meg. ${ }^{88}$

A törvénymódosítást követően a Közeü.tv. rögzíti a koronavírus-járvány elleni védekezés során használt fogalmakat, ${ }^{89}$ több olyat is, amelynek korábban - szükség híján - nem volt törvényi definíciója, példának okáért a személyek közötti „védőtávolság” fogalmát, amelynek mértékét a Holland Népegészségügyi és Környezetvédelmi Intézet (Rijksinstituut voor Volksgezondheid en Milieu) határozza meg..$^{90} \mathrm{~A}$ védôtávolságot az otthonán kívül mindenki köteles betartani, ${ }^{91}$ kivéve az 58f. cikk (3) bekezdésében rögzített kivételek hatálya alá tartozó személyeket. A kivételek hatálya alá tartoznak azok, akik egy háztartásban élnek, vagy akik meghatározott tevékenységet végeznek, és e tevékenység jellegéből adódóan a védőtávolság betartása esetén a munkájukat nem tudnák elvégezni (e kategóriába tartoznak többek között az orvosok, ápolók és a rendőrök is).

A Közeü.tv. értelmében a kormány miniszteri rendeletekben rögzíti a járvány elleni védekezéshez szükséges intézkedéseket.92 A rendeletet a kibocsátását követő két napon belül meg kell küldeni a törvényhozás mindkét házának. ${ }^{93} \mathrm{~A}$ törvényhozás egy héten belül dönt a rendelet megerősítéséről, amely a határidő lejárta előtt, illetve a törvényhozás bármely házának elutasító döntése esetén nem lép hatályba. E szabálytól csak abban az esetben lehet eltérni, amennyiben olyan sürgetố körülmény (dringende omstandigheid) áll fenn, amely a veszély azonnali mérséklését szolgáló intézkedés meghozatalát követeli meg. ${ }^{94} \mathrm{Az}$ elfogadást követő két napon belül a rendeletet - a kényszerítő okokat részletező levél kíséretében - továbbítani kell a törvényhozás két házának jóváhagyásra. Amennyiben a törvényhozás bármely háza egy héten belül leszavazza a sürgetô körülmény miatt hozott rendeletet, úgy az hatályát veszti.

A Közeü.tv. pontosítja, hogy az egészségügyi miniszter - mely törvényi szempontok figyelembevételével és milyen személyi körrel folytatott konzultációt követően - ruházhatja a biztonsági körzet vezetőjére az egyébként a polgármestereket megillető jogkörök gyakorlását, ideértve az Önkormányzati tv. 125. cikkében rögzített szankcionálási jogkört. ${ }^{95} \mathrm{~A}$ törvény e tekintetben tehát egyrészt új jogalapot teremtett a hatáskör-átruházásra

87 Tijdelijke wet maatregelen Covid-19 (Wet van 28 oktober 2020). Lásd továbbá: The Brussels Times (27 October 2020): Netherlands Adopts 'Corona Law' to Give Legal Base to Lockdown. Elérhető: www.brusselstimes.com/news/ world-all-news/137888/mask-public-space-mark-rutte-netherlands-adopts-corona-law-to-give-legal-baseto-lockdown/ (Letöltve: 2020. december 15.).

88 Abban bízva, hogy az oltás révén addigra a bevezetett rendelkezések szükségtelenné válnak.

89 Közeü.tv. 58a. cikk.

90 Közeü.tv. 58f. cikk (2) bekezdés.

91 Közeü.tv. 58f. cikk (1) bekezdés.

92 Közeü.tv. 58c. cikk (1) bekezdés.

93 Közeü.tv. 58c. cikk (2) bekezdés.

94 Közeü.tv. 58c. cikk (3) bekezdés.

95 Közeü.tv. 58d. cikk. 
a Közeü.tv. sokat kritizált 6. és 7. cikkei helyett; másrészt pontot tett arra a fentebb említett jogértelmezési kérdésre, hogy a hatáskör-átruházás magában foglalja-e a szankcionálási jogkör átruházását.

A Közeü.tv. rögzíti a kormány azon jogát, hogy betiltson bármilyen létszámú gyülekezést, korlátozza vagy feltételhez kösse a zárt térben történő vallásgyakorlást, továbbá hogy feltételekhez kösse, korlátozza vagy betiltsa egyes nyilvános helyek látogatását, az éttermek, a szállodák és egyéb szabadidős tevékenységek helyszínéül szolgáló létesítmények múködését. ${ }^{96}$ Ily módon tehát e kérdések is törvényi szinten, megfelelő garanciák mentén kerülnek korlátozásra. A törvény rendelkezik a fentebb említett rendelkezések megsértőivel szemben kiszabható bírságokról is.97

\section{A különleges jogrend kihirdetésének gyakorlati esetei és az azokat övező politikai és közjogi viták}

Az alkotmány legutolsó - 1983-as - reformja óta nem került sor az alkotmány 103. cikkében rögzített szükségállapot kihirdetésére, katasztrófa- és krízishelyzetet viszont több alkalommal is kihirdetett a kormány. A 96. cikkben rögzítettek szerint háborús állapot csak a törvényhozás előzetes beleegyezésével hirdethető ki. A kormány e rendelkezés kapcsán egy olyan értelmezést próbált érvényesíteni, amely szerint a 96. cikk csak formális hadüzenet esetén alkalmazandó. Jóllehet ezen értelmezést a törvényhozás alsóháza és a Hágai Kerületi Bíróság is elfogadta, a szakirodalom kétségbe vonja annak megalapozottságát: az alkotmány ugyanis nem véletlenül alkalmazza a megállapító jellegú „háborúban áll” kifejezést a nemzetközi jogból szinte teljesen kikopott hadüzenet helyett. ${ }^{98}$ A 100. cikk kapcsán a törvényhozás szerepének csökkentésére irányuló kormányzati törekvés okozott közjogi vitát: a kormány értelmezése szerint a törvényhozást elegendő a kormány döntését követően informálni. A törvényhozás nem értett egyet ezen értelmezéssel.99

96 Közeü.tv. 58g., 58j., 58k. és 58m. cikk.

97 Közeü.tv. 58u. cikk.

98 Besselink, 2012, 15. o.

99 A kormány ezt azzal indokolta, hogy amennyiben a törvényhozás elutasító álláspontra helyezkedik a 100. cikk alkalmazása kapcsán, a kormány olyan helyzetbe kerülhet, hogy választania kell az országot kötelező nemzetközi szerződés megszegése és a törvényhozás kifejezett akaratával szembeni cselekvés lehetősége között. Ennek megfelelően a kormány arra az álláspontra helyezkedett, hogy a NATO-szerződés 5. cikkéből eredő kötelezettség teljesítése nem követeli meg a törvényhozás beleegyezését, következésképpen azt a kormány döntését követően is elég tájékoztatni. A kérdést vizsgáló parlamenti bizottság ezzel szemben arra a következtetésre jutott, hogy a törvényhozást azelőtt kell informálni, hogy a kormány meghozta volna az érdemi döntését, ellenkező esetben ugyanis a törvényhozás jogosítványai kiüresednek. Lásd: Report of the Tijdelijke commissie besluitvorming uitzendingen. Tweede Kamer der Staten-Generaal. Vergaderjaar 1999-2000 (26454, $\mathrm{nr}$. 8) (az elnöke után Bakker-bizottságként is ismert); lásd még: Besselink, 2012, 15. o. 
A koronavírus-járvány kezelését megelőzően utoljára a 2019 márciusában - az esetleges hard brexitre való felkészülés ${ }^{100}$ jegyében - elfogadott brexit-salátatörvény ${ }^{101}$ váltott ki a különleges jogrendet érintő közjogi vitát. ${ }^{102} \mathrm{~A}$ törvénytervezet eredeti változata kvázi biankó csekket adott volna a kormánynak: többek között akár rendeleti úton is hatályon kívül helyezhetett volna törvényeket meglehetősen korlátozott parlamenti ellenőrzés mellett. A kormány ilyen páratlan hatáskörökkel történő felruházását még a kormánypárti képviselők többsége sem támogatta. A törvényt végül a kormány által tett engedményeket követően fogadták el. ${ }^{103}$

Amint az előző fejezetben kifejtettük, a koronavírus-járvány kezelése érdekében nem került sor különleges jogrendi helyzet kihirdetésére. Ebben az esetben éppen ennek elmaradása generált közjogi vitát: egyes álláspontok szerint a kormány - ellentétben a saját maga által kínált narratívával - azért nem kért különleges felhatalmazást, hogy ily módon kerülje meg a különleges jogrend esetén érvényesülő demokratikus kontrollt és a jogállamisági garanciáknak való megfelelés kötelezettségét.

\section{5. Összegzés}

A holland szabályozás egy része a magyarhoz hasonlóan újnak - vagy viszonylag újnak - tekinthetô, és a különleges jogrendi kategóriák számát tekintve is hasonlítanak: míg a holland szabályozás négy, a hatályos magyar szabályozás hat különleges jogrendi helyzetet különböztet meg. ${ }^{104} \mathrm{~A}$ holland szabályozás kellően cizelláltnak tekinthető a négy, egymástól jól elkülöníthető különleges jogrendi helyzet megkülönböztetéséből, valamint a cselekvésre jogosultak körének alapos elhatárolásából kifolyólag. A magyar Alaptörvénnyel összehasonlítva megállapítható ugyanakkor, hogy a holland alkotmány szükségállapot idején több büntetőjogi garanciát tör át, mint az Alaptörvény.

A koronavírus-járvány kezelése kapcsán a holland kormány által választott válságkezelési stratégia felszínre hozta a holland különleges jogrendi szabályozásban - a Közeü.tv. módosításának 2020. december 1-jei hatálybalépése elôtt - rejlő hiányosságot. Jelesül azt, hogy a krízishelyzet esetére a Biztonsági körzetek tv. és az Önkormányzati tv. által garantált demokratikus kontroll és jogállamisági garanciák könnyedén megkerülhetők, amennyiben a kormány él a Közeü.tv. 6. és 7. cikkében rögzített felhatalmazással, és az egészségügyi mi-

100 A holland külügyminiszter 2018. szeptember 7-i levele az alsóháznak a brexitre való felkészülés aktuális állásáról.

101 Verzamelwet Brexit (Wet van 27 maart 2019).

102 Pieters, 2018.

103 Dutch News (25 January 2019) Dutch Water Down 'Undemocratic' Brexit Emergency Powers Legislation. Elérhető: www.dutchnews.nl/news/2019/01/dutch-water-down-undemocratic-brexit-emergency-powers-legislation/ (Letöltve: 2020. december 15.).

104 Jóllehet e szám - amint az fentebb említésre került - 2023. júliustól háromra csökken. 
niszter - átvéve a járvány elleni védekezés megszervezését - a biztonsági körzetek vezetőire ruházza az egyébként a polgármestereket megillető jogosultságok gyakorlását. A kormány az általa választott válságkezelési stratégiát ért kritikákra válaszul 2020 júliusában nyújtotta be a 2020. október végén elfogadott törvénymódosítást, amely egy új fejezetet iktatott a Közeü.tv. rendelkezései közé. Az új fejezet célja, hogy megteremtse a kormány által a vírus második hulláma elleni küzdelem során meghozandó intézkedések - alkotmányossági szempontból megfelelő - jogalapját, illetve a törvényhozás számára garantált felügyeleti jogkörök révén biztosítsa a demokratikus kontrollt. Tekintve, hogy az új törvény csak két héttel a kézirat lezárását megelőzően lépett hatályba, a hatását és az alkalmazását illetően megalapozott következtetéseket levonni egyelöre nem lehetséges, az azonban kijelenthető, hogy a törvényjavaslat előkészítése során figyelembe vették a kormány által választott válságkezelési stratégiát ért - a 3.2. pontban részletesen kifejtett -, a demokratikus elszámoltathatóság és a jogállamisági kritériumok érvényesülésének hiányára vonatkozó kritikákat. Ennek megfelelően az alkotmányos és törvényi szabályokkal összhangban lévő jogalapot teremtettek a meghozott válságkezelő intézkedések számára, illetve törvényileg szabályozták a korábban a jogalkalmazás során fellépő kérdéseket.

\begin{tabular}{|c|c|c|c|c|}
\hline & $\begin{array}{c}\text { Általános } \\
\text { szülkségállapot }\end{array}$ & $\begin{array}{c}\text { Korlátozott } \\
\text { szükségállapot }\end{array}$ & Katasztrófahelyzet & Krízishelyzet \\
\hline Szabályozás szintje & \multicolumn{2}{|c|}{ Alkotmányos és törvényi } & \multicolumn{2}{|c|}{ Törvényi } \\
\hline Elrendelési okok & $\begin{array}{l}\text { Az állam létét fer } \\
\text { belső vesze }\end{array}$ & $\begin{array}{l}\text { nyegető külső és } \\
\text { ély esetén. }\end{array}$ & $\begin{array}{l}\text { Olyan helyzetet jelöl, } \\
\text { amely komolyan } \\
\text { fenyegeti vagy veszé- } \\
\text { lyezteti az állampol- } \\
\text { gárok életét és jólétét } \\
\text { vagy a természeti } \\
\text { és épített környe- } \\
\text { zetet, és amelynek } \\
\text { elhárítása, illetve } \\
\text { a károk csökkentése } \\
\text { érdekében a ható- } \\
\text { ságok és egyéb szer- } \\
\text { vezetek összehangolt } \\
\text { munkája szükséges. }\end{array}$ & $\begin{array}{l}\text { A krízishelyzet } \\
\text { a társadalom } \\
\text { alapvető érde- } \\
\text { keinek veszé- } \\
\text { lyeztetését vagy } \\
\text { az azzal való } \\
\text { fenyegetést jelent. }\end{array}$ \\
\hline
\end{tabular}




\begin{tabular}{|c|c|c|c|c|}
\hline & $\begin{array}{c}\text { Általános } \\
\text { szülkségállapot }\end{array}$ & $\begin{array}{c}\text { Korlátozott } \\
\text { szülkségállapot }\end{array}$ & Katasztrófahelyzet & Krízishelyzet \\
\hline Elrendelés & \multicolumn{2}{|c|}{$\begin{array}{c}\text { Az uralkodó a miniszterelnök } \\
\text { javaslatára }\end{array}$} & $\begin{array}{l}\text { A helyi és regionális } \\
\text { önkormányzatok }\end{array}$ & A miniszterelnök \\
\hline Felhatalmazott & $\begin{array}{l}\text { A kormányzás f } \\
\text { az uralkodó, aki } \\
\text { javaslatára kira } \\
\text { révén irányítj }\end{array}$ & $\begin{array}{l}\text { elhatalmazottja } \\
\text { a miniszterelnök } \\
\text { ályi rendeletek } \\
\text { a az országot. }\end{array}$ & $\begin{array}{l}\text { Az önkormányzatok, } \\
\text { illetve amennyiben } \\
\text { az önkormányzatok } \\
\text { nem képesek kezelni, } \\
\text { a biztonsági körzet } \\
\text { vezetője. }\end{array}$ & $\begin{array}{l}\text { A biztonsági } \\
\text { körzet vezetője, } \\
\text { illetve szükség } \\
\text { esetén a Mi- } \\
\text { niszteri Szintű } \\
\text { Válságkezelő } \\
\text { Bizottság. }\end{array}$ \\
\hline Gyakorlati esetek & \multicolumn{2}{|c|}{$\begin{array}{l}\text { Az alkotmány 1983-as reformja } \\
\text { óta nem került kihirdetésre. }\end{array}$} & \multicolumn{2}{|c|}{ Számtalan esetben } \\
\hline $\begin{array}{l}\text { Rendkívüli felhatal- } \\
\text { mazás esetkörei }\end{array}$ & \multicolumn{4}{|c|}{$\begin{array}{l}\text { - A brexit-salátatörvény; } \\
\text { — a koronavírus-járvány kezelése érdekében a kormány nem kért külön- } \\
\text { leges felhatalmazást. }\end{array}$} \\
\hline
\end{tabular}

10. táblázat

Különleges jogrendi esetkörök Hollandiában

Forrás: a szerző saját szerkesztése

\section{Irodalomjegyzék}

Antonides, G., Van Leeuwen, E. (2020) 'Covid-19 Crisis in the Netherlands: Only Together We Can Control Corona', Mind \& Society [Online]. Elérhető: https://link.springer.com/ article/10.1007/s11299-020-00257-x (Letöltve: 2020. december 15.)

Bentzen, N., Boström, A., Del Monte, M., Odink, I., Prpic, M., Tuominen, M. (2020) States of Emergency in Response to the Coronavirus Crisis: Situation in Certain Member States III. [Online]. Elérhető: www.europarl.europa.eu/RegData/etudes/BRIE/2020/651972/EPRS_ BRI(2020)651972_EN.pdf (Letöltve: 2020. december 15.)

Besselink, L. (2012) 'The Legal and Constitutional Position of the Netherlands Armed Forces and International Military Cooperation' in Nolte, G. (szerk.) European Military Law Systems. 1. kiadás. Berlin: De Gruyter 
BROEKSTEEG, J. L. W. (2020) Corona en noodverordeningen [Online]. Elérhető: www.montesquieuinstituut.nl/id/vl7ah9uq3xl7/nieuws/corona_en_noodverordeningen (Letöltve: 2020. december 14.)

Buyse, A., De LAnge, R. (2020) The Netherlands: Of Rollercoasters and Elephants [Online]. Elérhetô: https://verfassungsblog.de/the-netherlands-of-rollercoasters-and-elephants/ (Letöltve: 2020. december 15.) DOI: 10.17176/20200508-133220-0

Cavalcanti, M. F., Terstegge, M. J. (2020) 'The Covid-19 Emergency in the Netherlands: A Constitutional Law Perspective', DPCE Online, 43(2), 1691-1710. o.

HENDRIKs, A. (2020) Nood breekt wet in Tijden van Corona [Online]. Elérhetố: www.navigator.nl/ document/idiba9e1943bfc4a9897e3dd333f0626a2/nederlands-juristenblad-nood-breektwet-in-tijden-van-corona?ctx=WKNL_CSL_85 (Letöltve: 2020 . december 15.)

HoRVÁTH, A. (2020) 'A veszélyhelyzet közjogi és jogalkotási dilemmái - mérlegen az Alaptörvény 53. cikke', Közjogi Szemle, 13(4), 17-25. o.

KeLEMEN, R. (2019) 'A különleges jogrend szabályozása az egyes alkotmányokban I. Általános alapvetés, fogalmi elhatárolás', Vélemények a Katonai Jog Világából, 2019/1.

Khakee, A. (2009) Securing Democracy? A Comparative Analysis of Emergency Powers in Europe. Geneva Centre for the Democratic Control of Armed Forces. Policy Paper No. 30/2009

Kuipers, S., BoIn, A. (2014) Crisis and Disaster Management in the Netherlands. A description of Structure and Processes. 1. kiadás. Leiden: Crisisplan BV

PIETERS, J. (2018) Dutch MPS Against Emergency Law for No-Deal Brexit [Online]. Elérhetö: https:// nltimes.nl/2018/12/12/dutch-mps-emergency-law-deal-brexit (Letöltve: 2020. december 15.)

Uzman, J., BArkhuysen, T., van Emmerik M. L. (2010) 'The Dutch Supreme Court: A Reluctant Positive Legislator?', Electronic Journal of Comparative Law, 14(3), 1-35. o.

van Den Hoven van Genderen, R. (2020) The New Netherlands Emergency Law: The Neverending Story of Privacy-and Other Fundamental Rights Containment on Basis of Corona [Online]. Elérhető: www.switchlegal.nl/the-new-netherlands-emergency-law-the-never-endingstory-of-privacy-and-other-fundamental-rights-containment-on-basis-of-corona/ (Letöltve: 2020. december 15.)

VAN DER KOLK, A. (2020) Coronavirus Breaking the Law? [Online]. Elérhető: www.rug.nl/ news/2020/03/corona-breekt-wet?lang=en (Letöltve: 2020. december 13.)

Wierenga, A. J., Brouwer, J. G. (2020) Coronacrisis en het recht (deel 8) De handhavers van de nooodverordening [Online]. Elérhető: www.openbareorde.nl/tijdschrift/coronacrisis-enhet-recht-deel-8/ (Letöltve: 2020. december 14.)

Wierenga, A. J., Schilder, A. E., Brouwer, J. G. (2020) Coronacrisis en het recht deel 13. Rechtvaardiging van noodverordeningen [Online]. Elérhető: www.openbareorde.nl/ tijdschrift/coronacrisis-en-het-recht-deel-13/ (Letöltve: 2020. december 14.) 